University of Michigan Law School

University of Michigan Law School Scholarship Repository

Law \& Economics Working Papers

2-1-2016

\title{
The SEC's Shift to Administrative Proceedings: An Empirical
} Assessment

\author{
Adam C. Pritchard \\ University of Michigan Law School, acplaw@umich.edu \\ Stephen Choi \\ NYU Law School, stephen.choi@nyu.edu
}

Follow this and additional works at: https://repository.law.umich.edu/law_econ_current

Part of the Administrative Law Commons, and the Judges Commons

\section{Working Paper Citation}

Pritchard, Adam C. and Choi, Stephen, "The SEC's Shift to Administrative Proceedings: An Empirical Assessment" (2016). Law \& Economics Working Papers. 119.

https://repository.law.umich.edu/law_econ_current/119

This Article is brought to you for free and open access by University of Michigan Law School Scholarship Repository. It has been accepted for inclusion in Law \& Economics Working Papers by an authorized administrator of University of Michigan Law School Scholarship Repository. For more information, please contact mlaw.repository@umich.edu. 


\title{
The SEC’s Shift to Administrative Proceedings: An Empirical Assessment
}

\author{
by Stephen J. Choi and A.C. Pritchard*
}

\begin{abstract}
Congress has repeatedly expanded the authority of the SEC to pursue violations of the securities laws in proceedings decided by its own administrative law judges, most recently in the Dodd Frank Act. We report the results from an empirical study of SEC enforcement actions against non-financial public companies to assess the impact of the Dodd Frank Act on the balance between SEC district court and administrative enforcement actions. We show a general decline in the number of court actions against public companies post Dodd Frank. At the same time, we show an increase in average civil penalties post-Dodd Frank for both court actions and administrative proceedings involving non-financial companies. Corresponding with the increase in civil penalties for administrative proceedings, we show an increase in two proxies for the complexity of the nature of the alleged underlying securities law violation, the disgorgement amount and the number of years during which the violation allegedly took place. Despite the increase in the complexity of the nature of the securities law violation, we report evidence that the egregiousness of the offense or the priority the SEC places on the action decreased for administrative proceedings after the enactment of Dodd-Frank. Overall, we conclude that the SEC has shifted weaker and/or lower priority cases to administrative proceedings post-Dodd Frank, allowing the agency to bring more cases. Although we cannot measure the deterrent impact of the additional cases that the shift to administrative proceedings has allowed the SEC to bring, it does appear that the SEC is using administrative proceedings to ramp up its enforcement efforts against public companies resulting in more marginal actions being brought in that forum.
\end{abstract}

"Choi is the Murray and Kathleen Bring Professor of Law, New York University. Pritchard is the Frances and George Skestos Professor of Law, University of Michigan. Thanks to Un Kyung Park for helpful comments. 


\section{Introduction}

Who should decide whether the law has been violated? Under the Constitution's traditional separation of powers, Article I authorizes Congress to make the laws, Article II charges the executive with prosecuting their violation, and Article III provides for an independent judiciary with life tenure to determine whether the violation has been proven (sometimes with the help of a jury). That tri-partite model was championed by the Framers of the Constitution as a bulwark of freedom. As Federalist 47 put it, "Where the whole power of one department is exercised by the same hands which possess the whole power of another department, the fundamental principles of a free constitution are subverted."

The advent of the New Deal swept into power Franklin Delano Roosevelt's cadre of progressives who championed the eventual triumph of the administrative state. The New Dealers chafed at the restraints imposed by the Framers' separation of powers model. The progressives' new science of public administration was premised on modern society's need for expertise in developing and implementing policy. Experts would be appointed to run agencies; those agencies would promulgate regulations to rein in the abuses of a modern, complex economy. Independent agencies would not be accountable to the executive, insulating them from political forces. Expert administrative tribunals would be better qualified than generalist judges to oversee the enforcement of rules devised by independent agencies.

Combining the functions of the legislature, executive, and judiciary in one body directly challenged the structure of government seemingly laid down by Articles I, II, and III, of the Constitution. Subversion or not, the Supreme Court has upheld independent agencies combining the three critical powers of government and they have become an established feature of the administrative state. To be sure, there was some pushback to perceived overreaching by the New 
Deal's "alphabet soup" independent agencies, most notably the enactment of the Administrative Procedure Act in 1946 ("APA"). ${ }^{1}$ The APA brought procedural regularity to the practices of the administrative agencies, as well as codification of judicial oversight to agency rulemaking and adjudication. Those checks proved sufficient to establish an uneasy truce between the administrative state and its critics. The passage of time has gradually established the independent agencies as an accepted, if not beloved, feature of modern government.

Among the independent agencies, the Securities and Exchange Commission ("SEC") has enjoyed a relatively favorable reputation for competence and efficiency, marred occasionally by the agency's failure to uncover the corporate scandal du jour with sufficient alacrity. For example, the SEC faced criticism for its failure to uncover Bernard Madoff's Ponzi scheme in the face of numerous warnings of Madoff's fraud. Even the SEC's failures, however, have ultimately redounded to its benefit. Over its history, the SEC has shown a remarkable facility to translate its failures into broader authority. Unhappy with how we are doing our job, Congress? We can fix the problem, if you will just give us more power! And Congress has repeatedly shown a willingness to oblige the SEC with additional enforcement tools. Granting the regulator greater authority is a tired and true means of showing that the legislators were "doing something" to respond to a perceived crisis. Indeed, the SEC owes its birth to the mother of all financial crises, the Great Depression.

Nowhere has the SEC's ability to convert its failures into a wider jurisdiction been more conspicuous than the realm of administrative proceedings. From their modest beginnings as a means of oversight over regulated entities, administrative proceedings have gradually taken over more and more of the field of securities law. Indeed, critics now worry that the SEC may entirely

\footnotetext{
${ }^{1}$ Pub. L. No. 79-404, 60 Stat. 237 (1946).
} 
abandon proceedings in federal court in favor of the "home court" advantage that it allegedly enjoys in its own administrative proceedings. Those enforcement cases are decided, in the first instance, by administrative law judges ("ALJs") employed by the SEC. In the wake of Congress's most recent expansion of the SEC's authority in administrative proceedings in the Dodd Frank Act of 2010, those proceedings have been subjected to heightened scrutiny by the media and constitutional challenges both before the SEC itself and in court.

This paper evaluates the consequences of the expanded use of administrative proceedings by the SEC. First, it explains the gradual erosion of limits on the SEC's authority to proceed before administrative tribunals. We also discuss recent constitutional challenges to that authority. We then look at the consequences for public companies of the SEC's expanded jurisdiction. In particular, we address this question: Has the SEC used administrative proceedings to pursue weaker or lower priority cases?

\section{SEC Administrative Proceedings}

Established in 1934, the SEC was charged with bringing Wall Street to heel. The agency earned its stripes early by confronting regulated entities such as exchanges and utilities, often in administrative proceedings. The agency's first two decades were occupied with dismantling the octopus-like public utility conglomerates, cutting them down to a more-readily regulated size. ${ }^{2}$ Along the way, the Supreme Court endorsed the SEC's discretion to use administrative proceedings to develop the law. The SEC was not required to proceed through the cumbersome process of rulemaking; it could announce new rules in the course of administrative adjudication. ${ }^{3}$

\footnotetext{
${ }^{2}$ See generally Joel Seligman, The Transformation of Wall Street 213-264 ( $3^{\text {rd }}$ ed. 2003).

${ }^{3}$ SEC v. Chenery Corp., 332 U.S. 194 (1947).
} 
After a fallow period in the 1950s, the SEC re-established itself in the 1960s as an activist agency when President John F. Kennedy appointed law professor William Cary to be its chairman. One of Cary's opening shots in revitalizing the agency was an administrative decision, In re Cady Roberts \& Co. ${ }^{4}$ In Cady Roberts, the SEC announced a novel interpretation of Rule 10b-5 of the Securities Exchange Act of 1934. ${ }^{5}$ Rule 10b-5 is the catch-all antifraud provision of the Exchange Act, adopted by the SEC two decades earlier under its $§ 10(b)$ authority. ${ }^{6}$ The rule (and its $\S 10(b)$ statutory authority) makes no mention of insider trading. Cary interpreted the rule, however, to prohibit not only garden-variety deception relating to the purchase or sale of securities, but also the exploitation of confidential information by corporate insiders: insider trading. Cary gave notice that in interpreting "[the] elements [of $\S 10(b)]$ under the broad language of the anti-fraud provisions we are not to be circumscribed by fine distinctions and rigid classifications." 7

The SEC was able to adopt its interpretation of Rule 10b-5 in an administrative proceeding because the respondent was a broker-dealer. The brokerage firm had received inside information from one its partners, who happened to also serve as a director of public company. Broker-dealers, like investment advisers and other regulated entities, were subject to SEC administrative proceedings from the agency's beginning. ${ }^{8}$ The fiction was that the regulated entity had consented to oversight by the agency, including administrative enforcement actions, when it registered to do business in that regulated industry.

\footnotetext{
${ }^{4} 40$ SEC 907 (1961).

517 C.F.R. $\S 240.10 b-5$.

${ }^{6}$ Exchange Act $\$ 10(\mathrm{~b})$.

${ }^{7}$ Cady Roberts, 40 SEC at 912.

${ }^{8}$ Exchange Act $\S 15(\mathrm{~b})$.
} 
Decisions in administrative proceedings are subject to judicial oversight. Initial decisions by ALJs can be appealed to the five-person Commission, ${ }^{9}$ and the Commission's decisions can be appealed to the federal court of appeals. ${ }^{10}$ That appellate review, however, is limited. The SEC's decisions are given substantial deference by the appellate courts. Findings of fact cannot be overturned if they are supported by "substantial evidence."11 Moreover, the SEC's legal interpretations of the securities laws may also be entitled to deference under the Chevron doctrine if the statute is ambiguous. ${ }^{12}$

Although the SEC had authority to bring administrative proceedings against regulated entities at the time of the Cady Roberts decision, the agency could only seek remedial sanctions. In Cady Roberts, for example, the partner of the broker-dealer was suspended from trading for 20 days, and the firm itself was not sanctioned at all. ${ }^{13}$ More serious misbehavior was referred to the Department of Justice for criminal prosecution. ${ }^{14}$

The SEC's authority was expanded to include punitive sanctions in the 1980s. The impetus was Congress' desire to demonstrate how tough it could be on insider trading. The first step was the Insider Trading Sanctions Act of 1984, which gave the SEC authority to seek treble damages in insider trading cases. ${ }^{15}$ For the first time, the agency could seek civil penalties. It could only seek those penalties, however, in federal court. Insider trading scandals continued to dominate the news in the mid-1980s. In response, Congress enacted the Insider Trading and

${ }^{9} 17$ C.F.R. $\S 201.110(2015)$.

${ }^{10} 15$ U.S.C. $\$ 78 y(a)(1)$.

${ }^{11}$ Administrative Procedure Act $\S 706,5$ U.S.C. § 706; NLRB v. Universal Camera Corp., 340 U.S. 47, 478-479 (1951) (applying substantial evidence standard).

${ }^{12}$ Chevron U.S.A. Inc. v. Natural Resources Defense Council, Inc., 467 U.S. 837 (1984).

${ }^{13}$ Cady Roberts, 40 SEC at 917-918.

${ }^{14}$ Paul S. Atkins \& Bradley J. Bondi, Evaluating the Mission: A Critical Review of the History and Evolution of the SEC Enforcement Program, 13 Fordham J. of Corp. \& Fin. L. 367, 384 (2008).

${ }^{15}$ Insider Trading Sanctions Act of 1984, Pub. L. No. 98-376, § 1, 98 Stat. 1264 (1984). 
Securities Fraud Enforcement Act of $1988 .{ }^{16}$ That law authorized the SEC to seek penalties against control persons of insider traders, again in federal court.

The big expansion in the SEC's penalty authority came two years later, with the Securities Enforcement Remedies and Penny Stock Reform Act of 1990 ("Penny Stock Act"), which for the first time authorized the SEC to impose money penalties in its administrative proceedings. ${ }^{17}$ That authority was limited, however, to entities directly regulated by the SEC, such as broker-dealers (who had been subject to administrative proceedings from the beginning). The Penny Stock Act also gave the SEC the authority to seek penalties against non-regulated entities, but only if it filed an enforcement action in federal court. In addition, the SEC was given the ability to pursue orders barring persons from serving as officers and directors of public companies, but again, only in federal court. The SEC was given more limited "cease-and-desist" authority over non-regulated entities in its administrative proceedings, along with the power to order disgorgement of illegally obtained gains. Thus, the SEC had authority to seek civil penalties against anyone violating the securities laws in federal court, but in its own administrative proceedings, the agency could only impose remedial sanctions on non-regulated entities. Congress was concerned that if the SEC had the same authority in judicial and administrative proceedings, the agency would have an incentive to shift to administrative proceedings to avoid scrutiny from an Article III judge. ${ }^{18}$ The penalty authority that Congress gave the SEC was sparingly used; between 1990 and 2002, the SEC brought only four actions

\footnotetext{
${ }^{16}$ Pub. L. No. 100-704, § 1, 102 Stat. 4677 (1988).

${ }^{17}$ Securities Enforcement Remedies and Penny Stock Reform Act of 1990, Pub. L. No. 101-429, 104 Stat. 931 (1990).

${ }^{18}$ Paul S. Atkins \& Bradley J. Bondi, Evaluating the Mission: A Critical Review of the History and Evolution of the SEC Enforcement Program, 13 Fordham J. of Corp. \& Fin. L. 367, 393-394 (2008).
} 
seeking money penalties against non-regulated entities. ${ }^{19}$ Moreover, the penalties sought were $d e$ minimis: less than $\$ 5$ million in total. ${ }^{20}$ The SEC did not appear to have much interest in using its limited penalty authority.

The SEC's thirst for penalties increased exponentially after the collapse of Enron and WorldCom in the early 2000s. Beginning with a $\$ 10$ million penalty assessed against Xerox in $2002,{ }^{21}$ SEC penalties against public corporations have skyrocketed. Since 2000, penalties have increased by at least $30 \%$ annually. ${ }^{22}$ Partially fueling the SEC's new-found enthusiasm for corporate penalties may be the "Fair Funds" provision adopted by Congress as part of the Sarbanes-Oxley Act. ${ }^{23}$ The Fair Funds provision allows the SEC to distribute penalties obtained from wrongdoers to compensate harmed shareholders, a politically popular initiative. ${ }^{24}$ At the end of fiscal year 2014, the director of the SEC's Division of Enforcement, Andrew Ceresney, was trumpeting that his unit had "obtained orders for over $\$ 4$ billion in monetary sanctions nearly $20 \%$ larger than our previous high."${ }^{, 25}$

Congress has enthusiastically endorsed the SEC's ramping up of penalties. (Not surprising, perhaps, given that most of the amounts collected by the SEC go to the U.S. Treasury, despite the Fair Funds provision added by Sarbanes-Oxley.) The SEC's role in the events leading to the financial crisis of 2008-2009 was widely criticized, particularly its supervision of risk-

${ }^{19}$ Id. at 394

${ }^{20} \mathrm{Id}$.

${ }^{21}$ Xerox Corp., Litig. Rel. No. 17465, 77 SEC Docket 971 (April 11, 2002).

${ }^{22}$ Sonia A. Steinway, Comment, SEC “Monetary Penalties Speak Very Loudly,” But What Do They Say? A Critical Analysis of the SEC's New Enforcement Approach, 124 Yale L.J. 209, 209-10 (2014).

${ }^{23}$ Pub.L. 107-204, 116 Stat. 745 (2002).

${ }^{24}$ Sarbanes-Oxley Act $\S 308$ (a). This provision only allowed the SEC to distribute penalties to shareholders when a court had ordered disgorgement. The SEC circumvented this restriction by negotiating settlements including nominal disgorgement amounts in order to allow for penalties to be distributed. See Bruce Carton, When a Dollar (of Disgorgement) Is Worth Millions, Sec. Class Action Serv., (Dec. 3, 2004), available at http://scas.issproxy.com/Newsletter/isscasDecember 2004.html\#POVEditorial. The Dodd Frank Act eliminated the need for this pretense by deleting requirement of disgorgement for penalties to be included in an SEC Fair Fund.

${ }^{25}$ Andrew Ceresney, Remarks to the American Bar Association’s Business Law Section Fall Meeting (Nov. 21, 2014), available at http://www.sec.gov/News/Speech/Detail/Speech/1370543515297. 
taking by large investment banks. That authority was taken away from the SEC by the Dodd Frank Act of $2010,{ }^{26}$ but what the SEC lost in supervisory power, it gained in enforcement authority. Most notably, the SEC gained the authority to impose civil penalties on non-regulated entities and individuals in its administrative proceedings. The caution that Congress showed in 1990 in expanding the SEC's penalty authority was cast aside in $2010 .^{27}$ After Dodd Frank, the SEC no longer needed to proceed in federal court in order to assess civil penalties. The SEC would need to go to federal court only in a narrow range of circumstances, such as when it needed emergency relief like an asset freeze or a temporary restraining order. ${ }^{28}$

The SEC did not immediately shift its enforcement efforts to administrative proceedings in response to the authority granted to it by the Dodd Frank Act, showing only a modest uptick in those proceedings between 2011 and 2013, before a sharp increase in $2014 .{ }^{29}$ Kara Brockmeyer, head of the SEC's Foreign Corrupt Practice unit, then described the shift to administrative proceedings as "the new normal." ${ }^{, 30}$ Her boss, Andrew Ceresney, defended the shift in a speech delivered to the American Bar Association. ${ }^{31}$ He identified a number of advantages of administrative proceedings, including faster decisions, the use of specialized factfinders, and more flexible evidentiary rules. ${ }^{32}$ He also argued that developing the law through the

\footnotetext{
${ }^{26}$ Dodd Frank Wall Street Reform and Consumer Protection Act, Pub. L. No. 111-203, 124 Stat. 1376, $1802(2010)$.

${ }^{27}$ See 15 U.S.C. $\S 77 \mathrm{~h}-1$ (2012) (Section 929P(a) of the Dodd Frank Act amending § 8A of the Securities Act, $\S 21 B(a)$ of the Securities Exchange Act, $\S 9(d)(1)$ of the Investment Company Act, and $\S 203(i)(1)$ of the Investment Advisers Act).

${ }^{28}$ A narrow category of actions can only be brought in an administrative proceeding. This category includes proceedings to terminate the registration of public companies for failure to file periodic reports, Exchange Act $\S 12(\mathrm{j})$, and "follow-on" administrative proceeding to bar persons or entities from the securities industry, based on a prior entry of a civil injunction or a criminal proceeding. See, e.g., Exchange Act § 15(b)(4). These proceedings tend to be open-and-shut and are rarely contested.

29 Jean Eaglesham, SEC Wins With In-House Judges, Wall Street Journal (May 6, 2015). 2014).

${ }^{30}$ Jean Eaglesham, SEC Is Steering More Trials to Judges It Appoints, Wall Street Journal (October 21,

${ }^{31}$ Ceresney, supra note 20.

${ }^{32}$ Id. at 4.
} 
administrative process was appropriate given the expertise that SEC commissioners have with the securities laws and the review provided by circuit court judges. ${ }^{33}$

The last point was an apparent response to Judge Jed Rakoff, a former federal prosecutor, who had criticized the SEC's expanded use of administrative proceedings. ${ }^{34}$ In Rakoff's view, ALJs might be inclined to a "narrow, tunnel vision view of the law." $" 35$ Expertise might come at the expense of independence. Other criticisms of the SEC's administrative proceedings are based on perceived unfairness to respondents. ${ }^{36}$ The first concern is the tight deadlines that the SEC imposes on its ALJs. ALJs are required to issue a decision within 300 days from the Enforcement Division's filing charges. The Division, of course, has had plenty of time to prepare its case through both informal and formal investigation (which gives the Division subpoena power): most investigations will last more than a year, and several years is not uncommon. Defendants must scramble to catch up once the case is filed, as they may not know the scope of the Division's case before receiving a Wells Notice (which typically occurs shortly before filing). Trials before ALJs typically begin about four months after filing. That can be a challenging timeline if the case involves a substantial number of documents (as is typical with the advent of electronic discovery) or requires expert testimony. Defendants have also claimed that the minimal discovery available in administrative proceedings limits their ability to obtain exculpatory evidence from the SEC. Although defendants may be given access to the Division's

\footnotetext{
${ }^{33}$ Id. at 5 .

${ }^{34}$ The Honorable Jed S. Rakoff, Judge, Southern District of New York, PLI Securities Regulation Institute Keynote Address: Is The S.E.C. Becoming a Law unto Itself? November 5, 2014, available at http://media.jrn.com/documents/secaddress.pdf.

${ }^{35}$ Stephanie Russell-Kraft, Rakoff Continues Crusade Against SEC Admin Courts, LAW360, Nov. 21, 2014, http://www.law360.com/articles/598561/rakoff-continues-crusade-against-sec-admin-courts (reporting on Rakoff's remarks at a panel at Columbia Law School.)

${ }^{36}$ A more detailed explanation of these critiques, along with suggestions for reform, can be found in U.S. Chamber of Commerce, Examining U.S. Securities and Exchange Commission Enforcement: Recommendations on Current Processes and Practices (July 2015), available at https://www.uschamber.com/press-release/us-chamber-sccmc-releases-report-sec-enforcement-practices-provides-recommendations.
} 
investigative file, that investigation has been shaped by the Enforcement Division attorneys who conducted the investigation. Depositions of witnesses, a routine part of civil litigation in federal court, are not typically available to defendants in administrative proceedings before the SEC unless the witness will not be available to testify at the administrative hearing. Although the SEC is also unable to depose witnesses, the SEC typically already will have collected substantial evidence through interviews prior to instituting the administrative proceedings. Overall, the process is considerably more streamlined than the procedures followed in federal court.

The SEC recently responded to these criticisms with proposals to amend the agency's Rules of Practice. The first proposal would relax the deadlines for administrative proceedings in three ways: (1) the deadline for the ALJ's initial decision would run from the time that the posthearing briefing is completed, rather than the date the proceeding was filed; (2) the timing of the initial hearing would change from four months after filing to a range of four months to eight months; and (3) allow for extension of the initial decision deadline by up to thirty days. ${ }^{37}$

The second proposal would expand the availability of depositions in administrative proceedings. The proposed rule would allow the Division and respondents to depose three persons per side in matters involving a single respondent, and five persons in matters involving multiple respondents. Parties could also request that the ALJ issue a subpoena for documents in conjunction with the deposition.

The SEC's proposed reforms would not make its administrative proceedings the equivalent of a federal court action, but they would blunt the most serious criticisms of the administrative process. The timing of these proposals is no accident; they were proposed by the SEC as the agency finds itself defending a number of constitutional challenges to its authority to 2015).

\footnotetext{
${ }^{37}$ SEC, Amendments to the Commission's Rules of Practice, Exchange Release No. 34-75976 (Sept. 24,
} 
bring cases in administrative proceedings. These challenges may have created a public relations problem, causing the agency to reform its procedures. Other potential reforms have been introduced in Congress, most notably, a proposal to allow respondents in administrative proceedings the option of removing their case to federal court. ${ }^{38}$ As we discuss in the next section, however, any constitutional barriers to the assignment of securities enforcement cases to administrative proceedings are likely to be temporary at best.

\section{Constitutional Challenges}

The SEC's recent shift to administrative proceedings has not gone unchallenged, and the initial challenges met with some success. The first post-Dodd Frank constitutional challenge arose in an insider trading case. Rajat Gupta was alleged to be a co-conspirator, along with 27 others, in the Galleon Hedge Fund insider trading scandal. The 27 others were sued in federal court by the SEC; the last case, Gupta's, was filed as an administrative proceeding. ${ }^{39}$ Gupta filed suit in federal court challenging the SEC's administrative proceeding against him on equal protection grounds, arguing that he was being targeted as a class of one. ${ }^{40}$ The district court temporarily enjoined the administrative proceeding, holding that it had jurisdiction to hear Gupta's equal protection claim. ${ }^{41}$ Rather than have the district court resolve the constitutional issue, the SEC backed down, refiling its case against Gupta in federal court.

The SEC has stuck to its guns in subsequent cases, however, arguing that district courts do not have jurisdiction to entertain constitutional challenges to the agency's administrative proceedings. As the SEC has filed more administrative proceedings - the "new normal' - the

\footnotetext{
${ }^{38}$ Due Process Restoration Act of 2015, H.R. 3798 (introduced October 22, 2015).

${ }^{39}$ SEC, Order Instituting Proceedings, In re: Rajat K. Gupta, No. 3-14279.

${ }^{40}$ Gupta v. SEC, 796 F. Supp. 2d 503 (S.D.N.Y. 2011).

${ }^{41}$ Id. at 513-514.
} 
"class of one" argument has faded away, and defendants are now relying on Article II challenges under the Appointments Clause. ${ }^{42}$ Article II stipulates that the President:

shall nominate, and by and with the Advice and Consent of the Senate, shall appoint ... all other Officers of the United States, whose Appointments are not herein otherwise provided for, and which shall be established by Law: but the Congress may by Law vest the Appointment of such inferior Officers, as they think proper, in the President alone, in the Court of Law, or in the Heads of Departments. ${ }^{43}$

These Article II challenges take two forms: 1) the SEC's ALJs are "inferior officers" who must be appointed by the head of an executive department, i.e., the SEC; and 2) the SEC's ALJs are unconstitutional because they are insulated from oversight by the President by more than one layer of "for cause" removal.

The inferior officers argument is straightforward textual argument; the only question that needs to be answered is whether ALJs are "inferior officers" or employees. The key Supreme Court precedent here is Freytag v. Comm'r ${ }^{44}$ in which the Supreme Court held that a special trial judge of the tax court was an "inferior officer." ${ }^{, 45}$ The SEC has taken the position that its ALJs, who presently are hired in a process administered by the U.S. Office of Personnel Management, are employees rather than officers because their decisions are not final until they are adopted by the Commission. In addition, the SEC reviews the decisions of its ALJs de novo. ${ }^{46}$ In rejecting the challenge to its ALJs, the SEC relied on the D.C. Circuit's decision in Landry v. Federal Deposit Insurance Corp. ${ }^{47}$ which held that the FDIC's ALJs were not inferior officers because they did not have the authority to render final decisions. Landry itself is open to question, as the

\footnotetext{
${ }^{42}$ Some cases have also asserted due process challenges based on the perceived unfairness of administrative proceedings.

${ }^{43}$ U.S. Const., Art. II, § 2.

${ }^{44} 501$ U.S. 868 (1991).

${ }^{45}$ See also Edmondson v. United States, 520 U.S. 651, 663 (1997) (“[M] ilitary trail and appellate judges are [inferior] officers.").

${ }^{46}$ In re Raymond J. Lucia Cos., Inc., Exchange Act Rel. No. 75837 (Sept. 3, 2015).

${ }^{47} 204$ F.3d 1125, 1132 (D.C. Cir. 2000).
} 
special trial judges in Freytag also lacked the authority to enter final decisions in most cases. It is not clear how the Supreme Court would interpret Freytag in the context of the SEC's ALJs. As a practical matter, however, any defect in the appointment of the SEC's ALJs can be easily corrected by having the Commissioners appoint the ALJs. The SEC has resisted that solution, presumably because it would call into doubt many previously-resolved cases, but Commission appointment of the ALJs would likely eliminate that constitutional question going forward. ${ }^{48}$

The second Appointments Clause issue relating to the Presidential oversight is also unlikely to derail the SEC's use of administrative proceedings. The SEC's ALJs can only be removed by the Commission for "good cause," as "established and determined" by the Merit Systems Protection Board ("MSPB"). ${ }^{49}$ The Commissioners themselves can only be removed by the President for "inefficiency, neglect of duty, or malfeasance in office." ${ }^{.50}$ The same limits apply to removal of the MSPB board members by the President. ${ }^{51}$ Thus, if the President wanted to remove an SEC ALJ from their position, he would face substantial obstacles.

The insulation that ALJs have from removal by the President looks a lot like the protections previously enjoyed by the members of the Public Company Accounting Oversight Board ("PCAOB") until the Supreme Court struck down those restrictions on removal. ${ }^{52}$ Although the Supreme Court had previously upheld for-cause restrictions on removal against constitutional attack, the $P C A O B$ Court deemed the layering of for-cause restrictions (SEC Commissioners could only be removed for cause, and PCAOB members could only be removed

\footnotetext{
${ }^{48}$ The Federal Trade Commission has already implemented this fix for its ALJs to ward off challenges. See Alison Frankel, Unlike SEC, FTC makes quick fix to ward off ALJ constitutional challenges, Reuters (Sept. 16, 2015).

${ }^{49} 5$ U.S.C. § 7521(a) (2012).

${ }^{50}$ Free Enterprise Fund v. Public Company Accounting Oversight Board, 561 U.S. 477, 487 (2010) (“PCAOB").

51 U.S.C. § 1202(d) (2012).

${ }^{52}$ PCAOB, 561 U.S. 477 (2010).
} 
for cause by SEC Commissioners) to unduly infringe on executive power. ${ }^{53}$ Although ALJs employed by independent agencies seem to enjoy at least as much protection, Chief Justice Roberts' opinion for the Court in $P C A O B$ distinguished their situation because, "unlike members of the [PCAOB], many administrative law judges of course perform adjudicative rather than enforcement or policymaking functions, or possess purely recommendatory powers. ${ }^{, 54}$ Justice Breyer, in dissent, challenged this distinction, arguing that the PCAOB did perform adjudicative functions, such as disciplining accountants and audit firms. ${ }^{55}$ Whatever the merits of the distinction drawn by Roberts, it is unlikely that the Supreme Court would have the collective stomach to invalidate the authority of the thousands of ALJs who allow the modern administrative state to function. Doing so would threaten to send a flood of trivial cases into federal courts. To avoid that headache, the Court is likely to find some form of "adjudication exception" to PCAOB's prohibition of double "for cause" removal. Alternatively, the Court could determine that the ALJs were employees rather than inferior officers, and therefore it is permissible to restrict their removal.

The constitutional challenges to the SEC's use of administrative tribunals will ultimately be resolved by the courts. Even if those challenges are rebuffed, however, the question remains: has Congress made the right policy choice in giving the SEC so much discretion in choosing between administrative proceedings and federal court? In the next section, we provide some empirical data relevant to that question. What has the shift to administrative proceedings meant for SEC enforcement actions and the public companies targeted in those actions?

\footnotetext{
${ }^{53}$ Id. at 509-510.

${ }^{54}$ PCAOB, 561 U.S. at 507 n. 10.

${ }^{55} \mathrm{Id}$. at 530-531 (Breyer, J., dissenting).
} 


\section{The Shift to Administrative Proceedings: Consequences}

To assess the consequences of the SEC's shift away from civil court and to administrative proceedings, we focus on enforcement actions involving public companies that are not financial institutions (defined as companies with Standard Industrial Classification (SIC) Code 6000 to 6999). Prior to the Dodd Frank Act, the SEC could impose monetary civil penalties in administrative cease-and-desist proceedings only against registered entities (including brokerdealers among other financial entities) and persons associated with these registered entities. The Dodd Frank Act gave the SEC authority to impose monetary civil penalties in all administrative cease-and-desist proceedings.

Our focus on non-financial public companies enables us to discern the impact of the Dodd Frank Act on SEC actions involving enforcement targets most affected by the Act. It also allows us to examine an important potential consequence of the SEC's enforcement efforts: Are enforcement actions filed as administrative proceedings different from those filed in court, particularly after the enactment of the Dodd Frank Act? Large penalties against public companies are intended to send a deterrent message to corporate actors generally, but the costs are born ultimately by the shareholders of the companies that pay the penalties. Those shareholders typically have done nothing wrong themselves and they have little leverage to affect the compliance efforts of the public companies that they invest in. The rationale for sanctioning companies is that it sends a deterrent message to similarly situated public companies. Although we cannot directly measure the deterrent message delivered by the SEC's enforcement actions, it is plausible that the strength of that message likely varies with the culpability of the conduct, the resources the SEC invests in the particular action, and the sanctions imposed. If 
administrative proceedings have lower indicia of culpability or lesser sanctions, the deterrent message is diluted.

To do our analysis, we began by collecting enforcement actions filed by the SEC against public companies (other than SIC 6000s) that are tracked by the Center for Research in Security Prices (CRSP). ${ }^{56}$ We collected all cases initiated against these companies between January 1 , 2005 and September 30, 2015. We obtain information about these actions from the NYU Securities Enforcement Empirical Database (SEED), the SEC's website, and Bloomberg Law (including information from court dockets tracked in Bloomberg Law) ${ }^{57}$ We started with a total of 324 SEC actions in our dataset.

We divide our dataset into two categories, civil cases filed in federal court or administrative proceedings before an ALJ. The graph below shows the trend over time of SEC enforcement actions against public companies.

${ }^{56}$ CRSP tracks companies that are traded on the NYSE, NYSE MKT, NASDAQ, and ARCA exchanges.

${ }^{57}$ The SEED database is available at seed.law.nyu.edu. 
Figure 1: Number of SEC Actions against Non-Financial Public Companies by Resolution Year

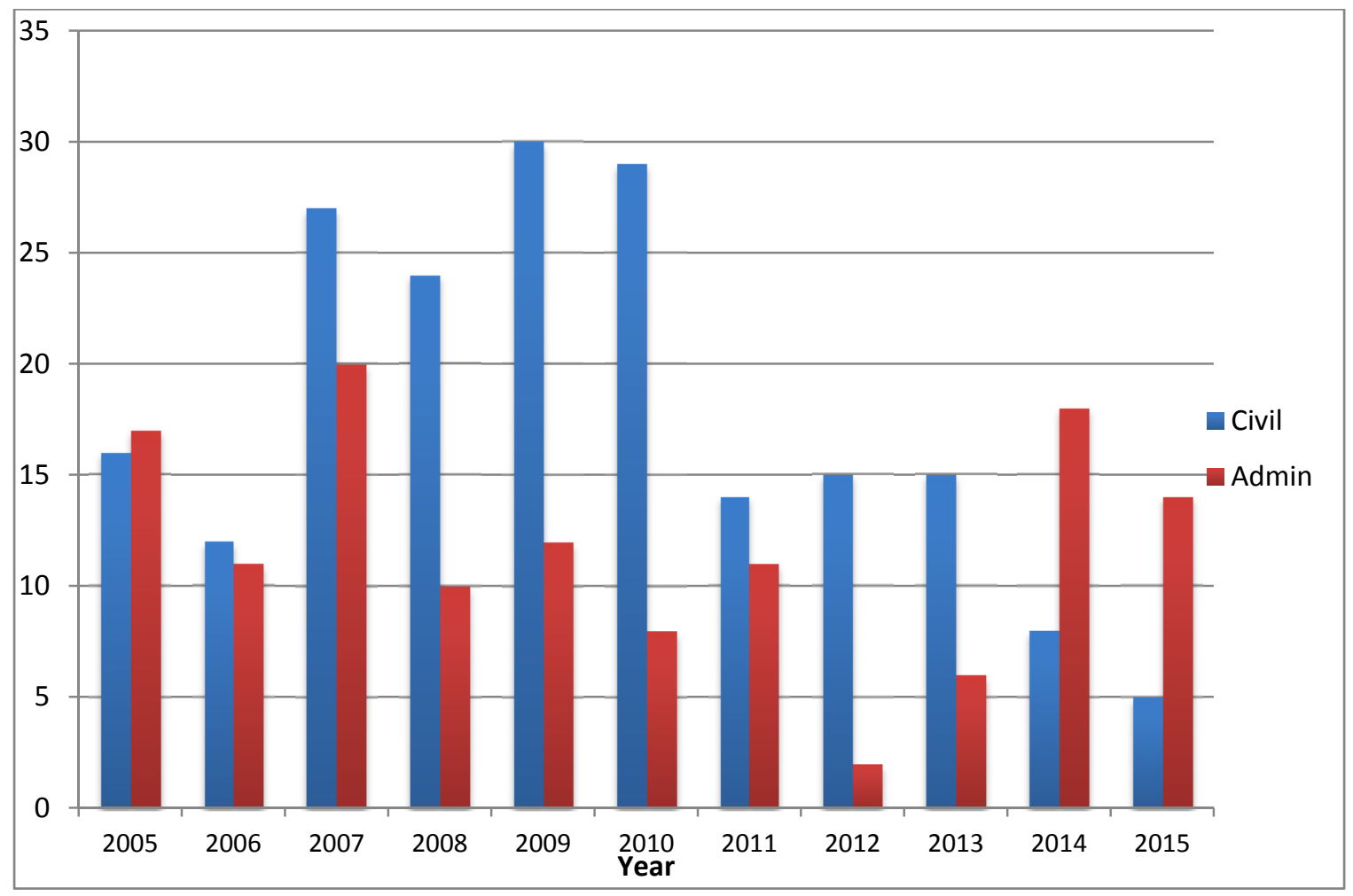

* The year 2015 only includes actions up to September 30, 2015, the end of the SEC's 2015 fiscal year.

We see an increase in civil actions resolved in court against public companies through 2010 (the year Dodd Frank was enacted), followed by a relatively rapid decline. In 2010, we tracked 29 newly initiated SEC civil enforcement actions against public companies while in 2014 we had only 8 civil actions, a drop of $72 \%$. This decline could be consistent with a shift from court actions to administrative proceedings. Administrative proceedings ebbed in 2012, before rebounding in 2013-2015. In 2010, we tracked 8 newly initiated SEC administrative enforcement actions, while in 2014, the last full year of our data sample, we had 18 newly initiated administrative actions, an increase of 125\%. Importantly, from 2006 to 2013, the number of civil actions against public companies was greater than the number of administrative proceedings. In 2014 and 2015 this relation reversed and the number of administrative proceedings was greater 
than the number of civil actions. These trends in initiated enforcement actions, however, might also reflect changes in the SEC's mix of cases between companies and individuals.

Consequently, the raw number of filings, even broken down between court actions and administrative proceedings, may not tell us too much, although the apparent decline in court proceedings post-Dodd Frank is suggestive.

The Dodd Frank Act, which gave the SEC wider penalty authority in administrative proceedings, was passed in July 2010. Accordingly, to avoid anticipation effects, we exclude SEC actions that were initiated or resolved in 2010 for our statistical analysis and divide the remaining cases into pre-Dodd Frank (2005-2009) and post-Dodd Frank (2011-2015). For our analysis, we also drop proceedings that were commenced prior to 2010, but not completed until after 2010. (Most cases are filed and simultaneously settled.) The dataset we used for our analysis consists of a total of 285 separate SEC enforcement actions.

The proportion of administrative proceedings appears to have increased since Dodd Frank was enacted in 2010, which is predictable given that Dodd Frank gives the SEC greater discretion in choosing a forum for its enforcement cases. If one assumes that prior to Dodd Frank the SEC brought its strongest or at least highest profile cases in court (because penalties were more widely available there), then one hypothesis is that the SEC would respond to Dodd Frank by shifting weaker cases from court into administrative proceedings, where the SEC would stand a better chance of prevailing. Alternatively, the SEC may shift lower priority cases in which it is less willing to devote resources toward administrative proceedings, if the "home court" advantage allows it to prevail with fewer resources. ${ }^{58}$ Such a shift would also produce both a mix

\footnotetext{
${ }^{58}$ Although the underlying substance of a case may drive the SEC's enforcement related decisions, it is also possible that other factors, including the political environment and the need to be seen as "doing something," particularly after a financial scandal, may affect the SEC's enforcement priorities.
} 
of stronger cases remaining in court (as weaker or lower priority cases migrate to administrative proceedings), albeit with a smaller number of court cases. Alternatively, adding to the enforcement possibilities in administrative proceedings might encourage the SEC to bring weaker cases, in terms of the cost to the SEC of bringing the action relative to the deterrent benefit from the action, as administrative proceedings that the agency would not have brought at all pre-Dodd Frank. The threat of penalties post-Dodd Frank might encourage respondents to settle an administrative proceeding that they previously would have been inclined to fight. Respondents may also be more willing to cooperate with the SEC's investigation and more receptive to adopting remedial changes to their operations. Overall, the SEC would be able to bring more cases, but their average strength might decline. Both the SEC and Congress focus on case numbers as a metric of the Enforcement Division's performance. Thus, theory predicts that the availability of penalties will encourage the SEC to bring more cases as administrative proceedings, but the strength of those cases is uncertain. Another prediction, however, is reasonably clear: Dodd Frank should increase the penalties the SEC collects in administrative proceedings by widening the range of defendants subject to penalties.

\section{Monetary Civil Penalties}

To dig deeper into the question of possible consequences from a shift to administrative proceedings, we collect the monetary penalties assessed in these enforcement actions against public companies, along with other non-monetary sanctions imposed. Prior to Dodd Frank, only entities directly regulated by the SEC (mainly broker-dealers and other financial entities) were subject to civil penalties in administrative proceedings; post-Dodd Frank, all public companies are included in the pool subject to penalties. In other words, the SEC has a wider range of 
potential targets for penalties in administrative proceedings after Dodd Frank. To assess the specific effect of Dodd Frank, we focus on non-financial industry firms, as defined above. Dodd Frank had the most immediate effect on the SEC's ability to assess monetary penalties in an administrative proceeding against those firms. Figure 2 shows the trend in average penalties preand post-Dodd Frank for non-financial services companies.

\section{Figure 2: SEC Civil Penalties for Non-Financial Industry Public Company Defendants}

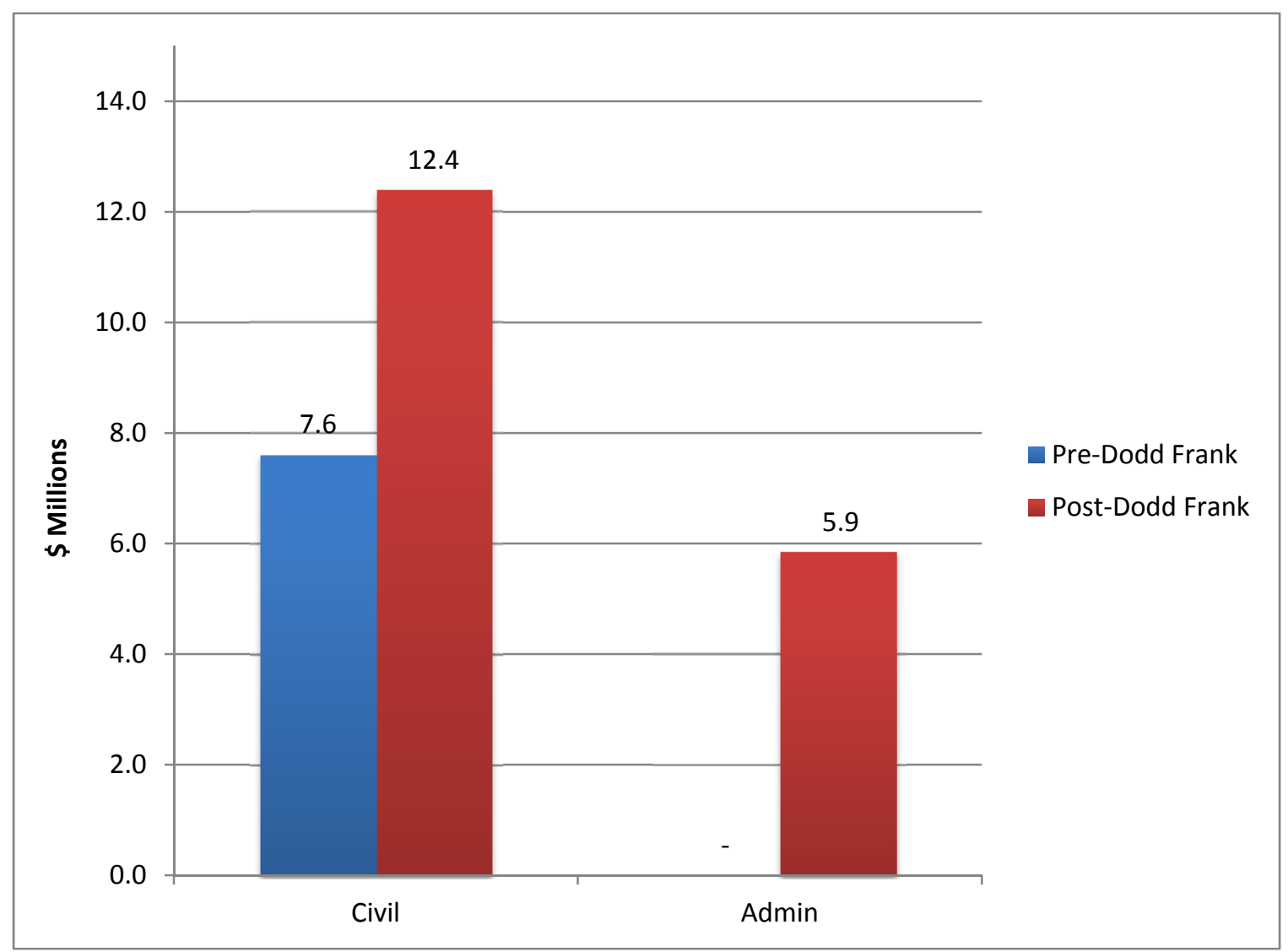

We see that Dodd Frank had an effect on civil penalties against public companies in administrative proceedings. Civil penalties for non-financial firms in administrative proceedings increased from $\$ 0$ in the pre-Dodd Frank period to a mean $\$ 5.9$ million penalty post-Dodd Frank. This change is statistically significant at the $10 \%$ confidence level. We also see a $\$ 4.8$ million 
increase in civil penalties in cases filed in federal court subsequent to Dodd Frank. This change, however, is significant at only at the $20 \%$ level, beyond conventional levels of statistical significance.

The increase in civil monetary penalties in administrative proceedings is consistent with two possible explanations. The first is that the SEC may not have changed the type of cases that it pursued in administrative proceedings, but rather, imposed civil penalties in administrative cases that would not have received a penalty prior to Dodd Frank. Alternatively, the SEC may have changed the type of cases it brings against public companies in administrative proceedings. Such a change could involve either shifting cases that the agency would have brought in court in the past, or targeting firms for enforcement that would not have been targeted pre-Dodd Frank.

\section{Case Complexity}

To get a sense of whether the SEC is imposing civil penalties on the same type of cases it would have brought in administrative proceedings prior to Dodd Frank or shifted the type of cases, we examine whether the SEC brought more complex actions in administrative proceedings post-Dodd Frank. More complex actions impose greater costs on the SEC, requiring the SEC to bear greater investigative and evidentiary costs. Post-Dodd Frank, the SEC may see administrative proceedings, which offers the SEC a quicker means of imposing sanctions, as more attractive for complicated actions.

First, we look at disgorgement as a measure of the underlying profits from the alleged securities law violation. Violations that involve greater profits are likely to be longer running and involve more transactions and participants. Both prior and after Dodd-Frank, the SEC had the power to seek disgorgement of ill-gotten gains in both civil and administrative proceedings. 
Looking to whether disgorgement changed therefore sheds light on whether the relative complexity of cases changed post-Dodd Frank. Figure 3 depicts the mean disgorgement amounts in millions of dollars for civil and administrative proceedings.

Figure 3: SEC Disgorgement for Non-Financial Industry Public Company Defendants

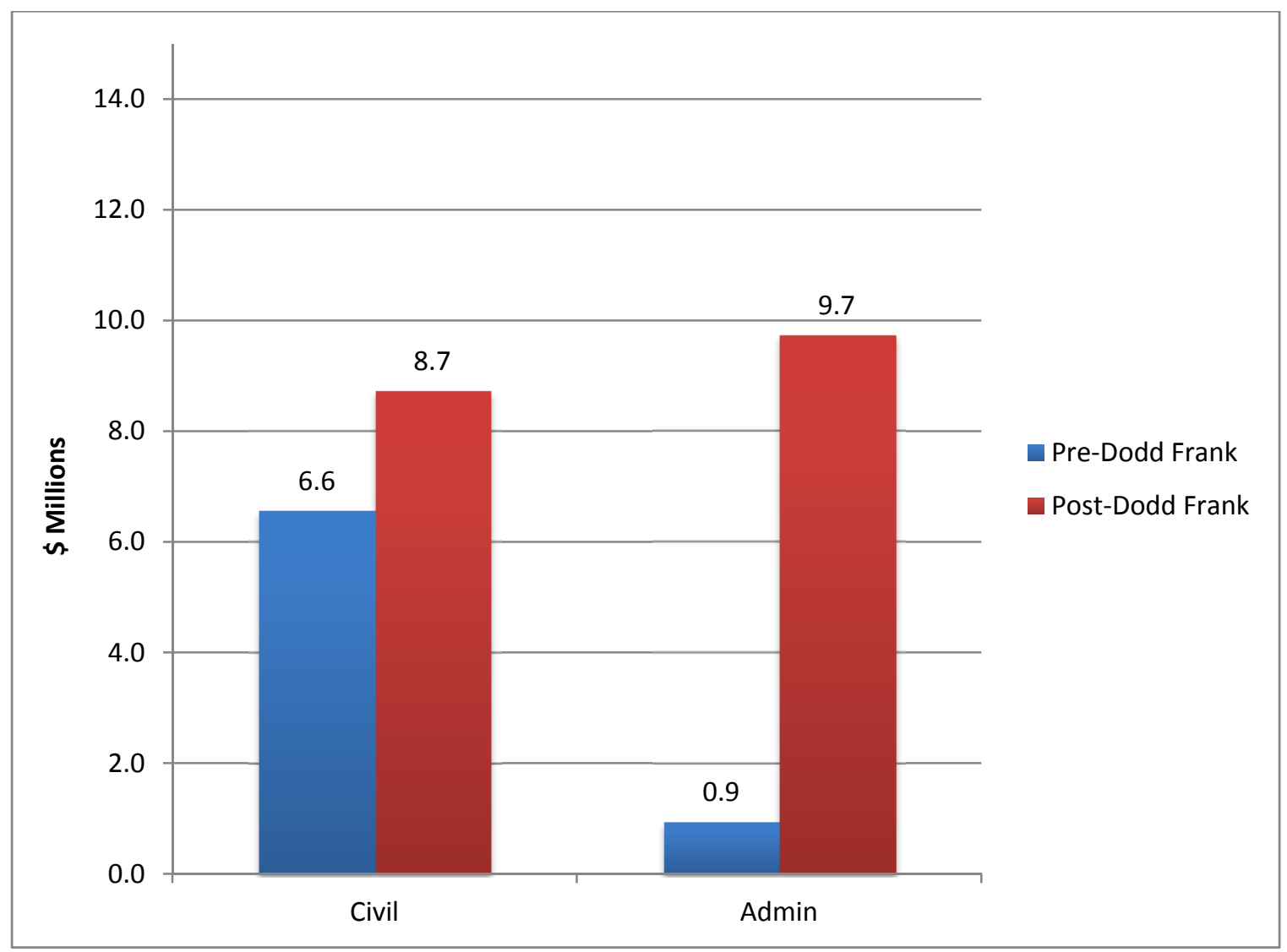

Note from Figure 3 that the mean disgorgement amount increases for both civil and administrative proceedings. The increase for civil actions of $\$ 2.2$ million is not statistically significant. The increase for administrative proceedings was both quantitatively larger at $\$ 8.8$ million and statistically significant at the $1 \%$ confidence level. The Dodd Frank Act corresponds with a shift by the SEC toward bringing more actions involving greater dollar profits in administrative proceedings. This shift is consistent with the SEC bringing more complex-and 
therefore more costly to enforce-actions in administrative proceedings now that civil monetary penalties are available there.

Another measure of the complexity is how long the alleged violation persisted. A pattern of securities law violations occurring over a number of years may pose greater evidentiary challenges for the SEC than would a single, discrete offense. Figure 4 compares the number of violation years for civil and administrative actions both prior to and after the enactment of the Dodd Frank Act.

Figure 4: Number of Violation Years for Non-Financial Industry Public Company Defendants

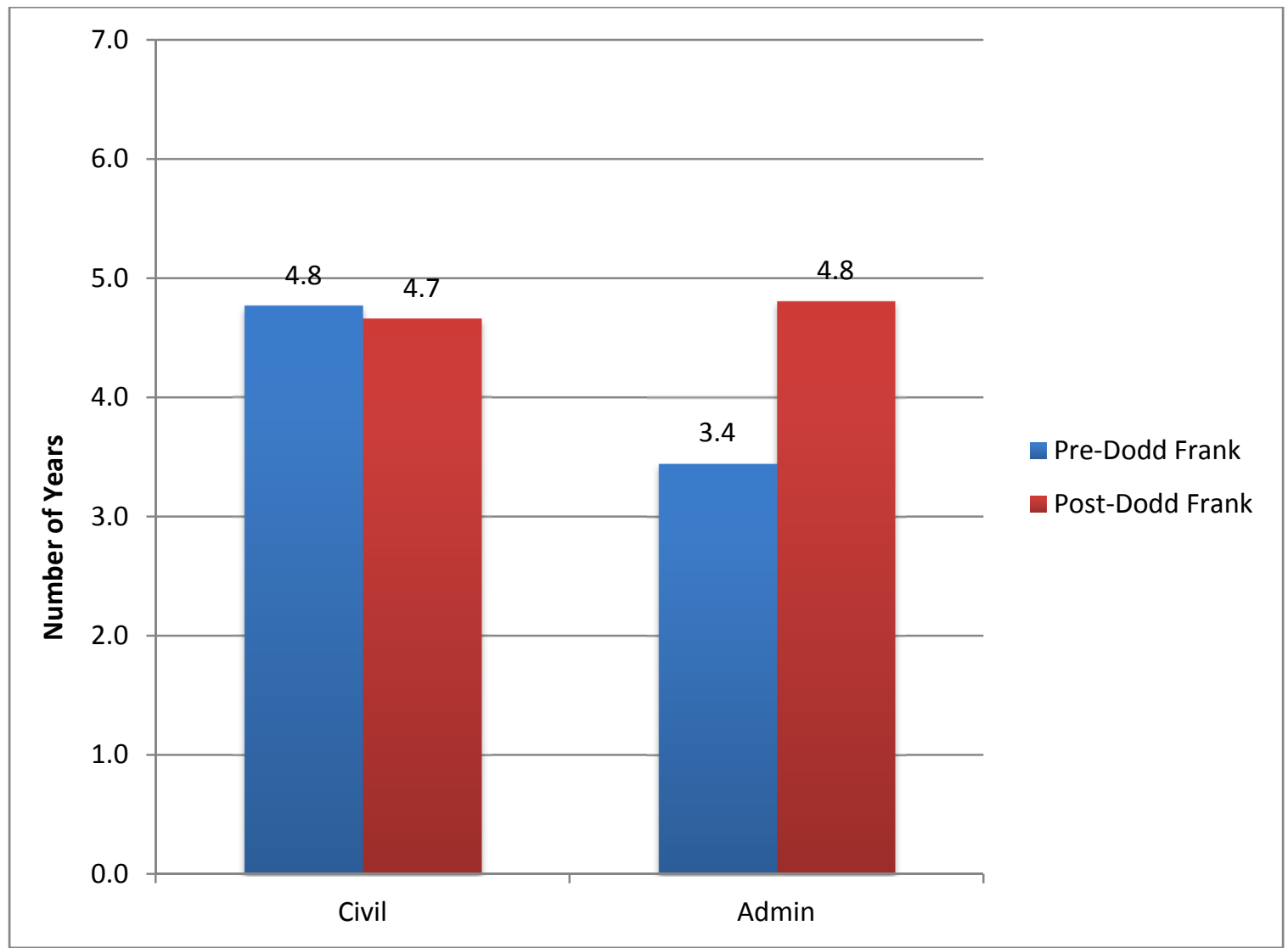

Note from Figure 4 that the number of violation years remains virtually unchanged for court actions, dropping from 4.8 years to 4.7 years. This difference is not statistically significant. 
In contrast, the number of violation years increases by $40 \%$ from 3.4 years to 4.8 years for administrative proceedings. This difference is significant at the $5 \%$ confidence level. The increase in violation years for administrative proceedings is consistent with the SEC bringing more complex and potentially more challenging cases in administrative proceedings after the enactment of the Dodd-Frank Act.

\section{Egregiousness of the Violation}

The shift by the SEC toward more complex actions in administrative proceedings is consistent with one of two possibilities. Post Dodd Frank, the SEC may have initiated administrative proceedings involving more egregious or higher priority violations that previously would have been filed in court. In this case, the shift toward more complex, and thus more costly, actions brought in administrative proceedings might be justified by the greater egregiousness or priority of the underlying securities law violation. Alternatively, the SEC may have initiated only marginal administrative proceedings that the SEC may have, prior to Dodd Frank, not brought at all. The case for the SEC bringing more complex and costly actions that correspond with less serious or lower priority securities law violations as administrative proceedings post Dodd Frank is open to doubt.

Is there evidence that the SEC is bringing weaker or lower priority cases in administrative proceedings after Dodd Frank? We look at several proxies for the egregiousness or priority of the SEC action. First, we look at the nature of the underlying securities law violation. In particular, we focus on whether the SEC action involves an accounting claim. We exclude accounting claims relating to the SEC's systematic efforts to address option backdating and FCPA violations. Both option backdating and FCPA enforcement, while involving accounting 
claims, may reflect priorities of the SEC other than solely investor protection and thus have less direct impact on investors. ${ }^{59}$ We focus instead on bread-and-butter accounting violations, which arguably pose the most risk to investors, allowing us to assess in what forum the SEC bring cases with the greatest impact on investors. Figure 5 compares the number of violation years for civil and administrative actions both prior to and after the enactment of the Dodd Frank Act.

${ }^{59}$ See Stephen J. Choi, A.C. Pritchard, and Anat C. Wiechman, Scandal Enforcement at the SEC: The Arc of the Option Backdating Investigations, 15 Am L. \& Econ. Rev. 542 (2013) (examining the role of media scrutiny on the SEC's option backdating enforcement actions). See Stephen J. Choi and Kevin E. Davis, Foreign Affairs and Enforcement of the Foreign Corrupt Practices Act, 11 J. Empirical Legal Stud. 409 (2015) (examining factors other than the egregiousness and extensiveness of bribes that affect FCPA sanctions including the nature of the country in which the bribe is made and the wealth and strength of legal institutions in the home country of the company making the bribe). 
Figure 5: Accounting Related SEC Actions against Non-Financial Industry Public Company Defendants

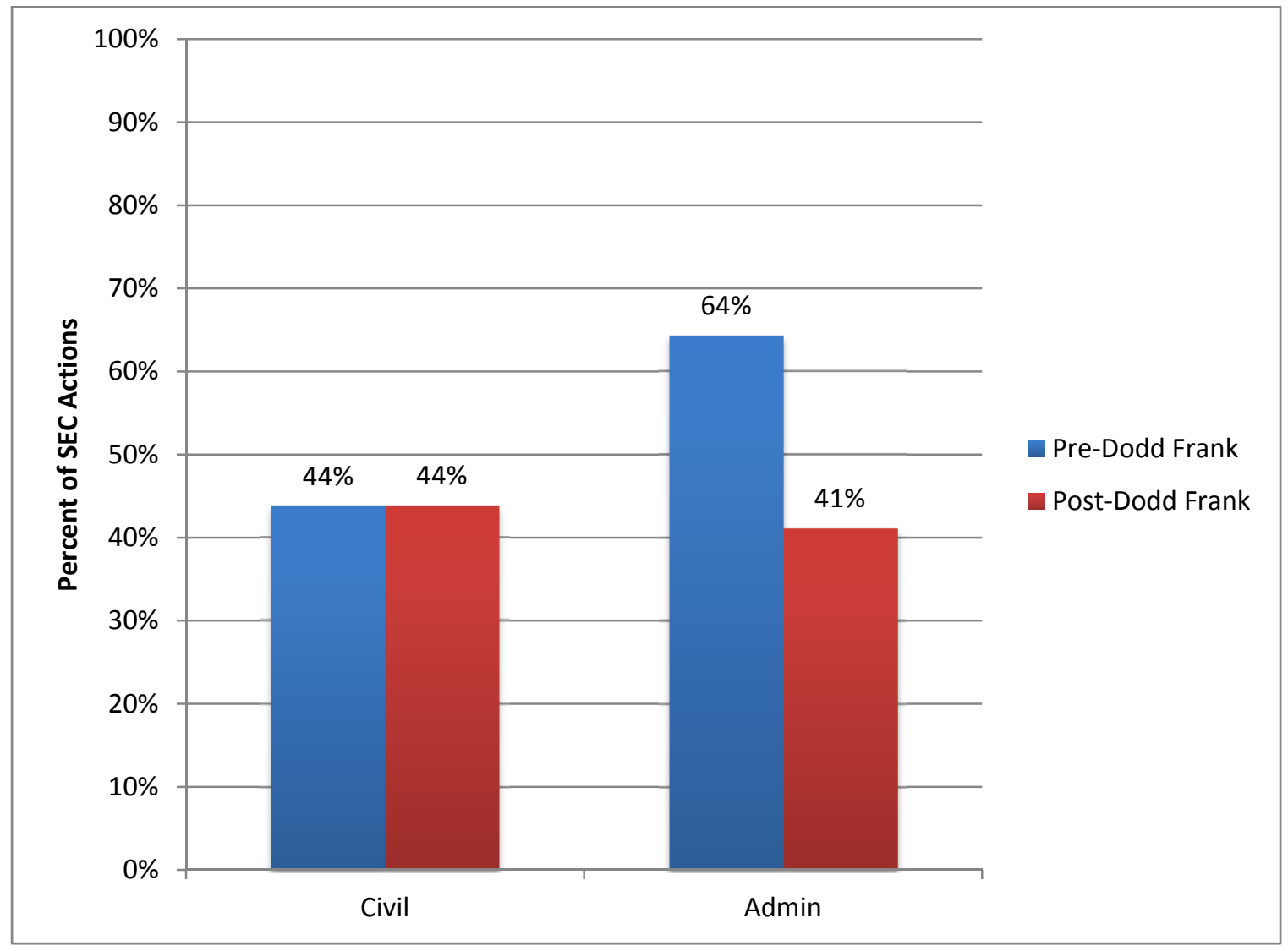

Note from Figure 5 that the fraction of court actions involving accounting claims remains unchanged after the enactment of Dodd Frank. In contrast, the fraction of administrative proceedings involving accounting claims drops precipitously, going from $64 \%$ down to $41 \%$ of the administrative proceedings, a reduction of $36 \%$. This difference is significant at the $5 \%$ level. After the enactment of Dodd-Frank, the SEC dramatically reduced the number of accounting allegations brought as administrative proceedings. To the extent the incidence of bread-andbutter accounting claims reflects the SEC's focus on violations with the greatest impact on investors, this shift is consistent with the SEC bringing more marginal actions in administrative proceedings post Dodd Frank. 
Second, we examine the incidence of independent consultants in the settlement with the SEC. As part of a settlement, firms will sometimes agree to accept oversight by an independent consultant as a remedial measure to avoid repetition of the violations alleged in the enforcement action. The SEC negotiates for independent consultants to promote compliance with the provisions of the federal securities laws and to evaluate the effectiveness of the companies' internal controls. Dealing with such consultants can be burdensome for management, interfering with their ability to focus on the day-to-day operations of the company. We assume that the SEC demands such settlement terms when the company is a high priority enforcement target and in cases that are relatively strong for the agency, i.e., there is substantial evidence of a compliance failure by the company. Figure 6 breaks down the incidence of independent consultants before and after Dodd Frank for non-financial public companies. 
Figure 6: Independent Consultants in SEC Actions against Non-Financial Public Companies

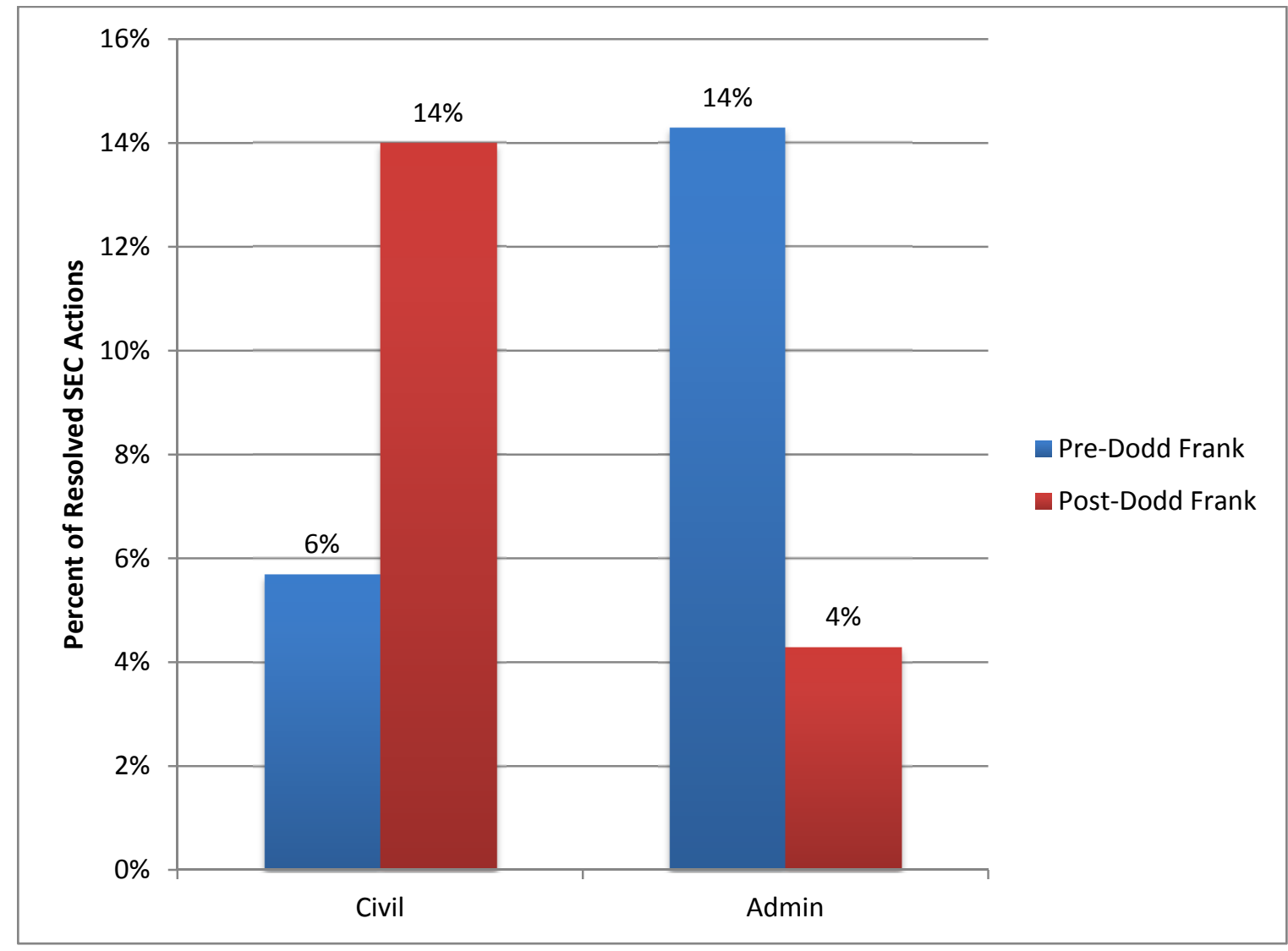

We see that independent consultants have become a more common feature of settlements after Dodd Frank, but only for cases filed in court. The percentage of SEC civil actions that resulted in the public company accepting an independent consultant rose from $6 \%$ prior to Dodd Frank to $14 \%$ after the enactment of Dodd Frank. This increase is significant at the $10 \%$ level and is consistent with the SEC bringing stronger or higher priority cases in court after Dodd Frank. In contrast, independent consultants became less common in administrative proceedings after Dodd Frank. The percentage of SEC administrative proceedings that resulted in the public company accepting an independent consultant decreased from $14 \%$ prior to Dodd Frank to $4 \%$ after the enactment of Dodd Frank. This difference is significant at the $10 \%$ level. After Dodd Frank, the SEC had reason to bring some of its relatively weaker or lower priority cases against 
non-financial institutions in administrative proceedings, which might account for the lower incidence of consultants in administrative actions.

Third, we look at external indicia of the strength of the SEC's case. One marker of a strong or high priority case is a parallel proceeding brought by another regulator that results in a penalty, such as a criminal proceeding brought by the DOJ and actions brought by state attorneys general. All else equal, a consensus among regulators that wrongdoing has occurred suggests relatively strong evidence of misconduct. Alternatively, the presence of an action by another regulator may indicate agreement among regulators that enforcement is needed and correspondingly a willingness to devote resources in targeting that public company. Figure 7 presents the trend in the fraction of SEC actions that also resulted in a penalty from another U.S. regulator pre and post-Dodd Frank for non-financial public companies. 
Figure 7: Other U.S. Regulator Penalties Against Non-Financial Public Companies

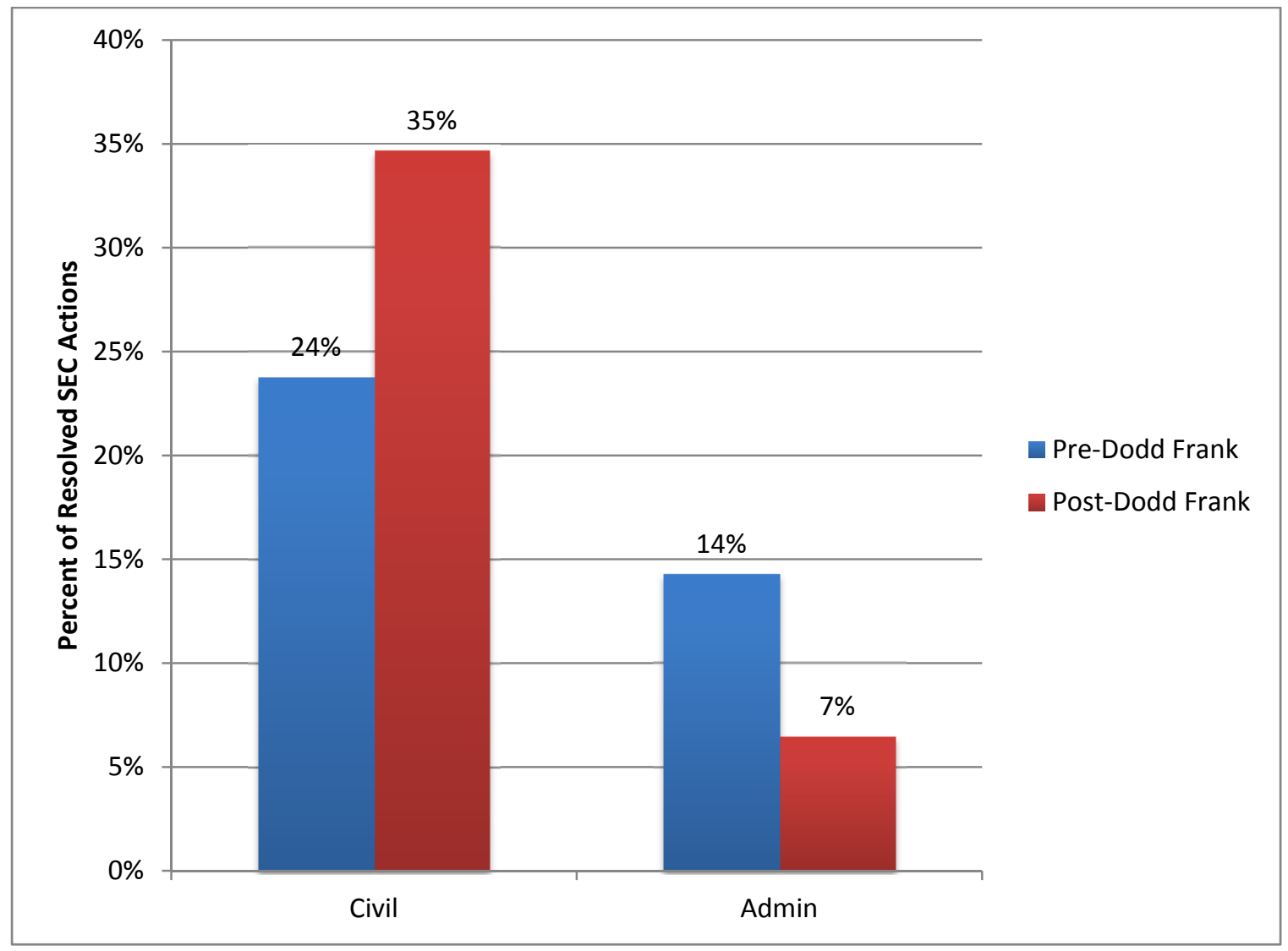

Overall, we see that the percentage of SEC court actions that also resulted in penalties from another regulator rose from 24\% prior to Dodd Frank to 35\% after the enactment of Dodd Frank. This increase is consistent with the SEC bringing stronger cases in court after Dodd Frank. In contrast, other regulators are less likely to pursue cases that the SEC brings as administrative proceedings. The incidence of other regulatory actions declines in administrative actions post-Dodd Frank from 14\% down to $7 \%$. This pattern is consistent with weaker or lower priority cases involving non-financial public companies migrating to administrative proceedings post-Dodd Frank. The changes for civil actions and administrative proceedings are significant at only the $16 \%$ and $20 \%$ levels, however, beyond conventional significance levels. Nonetheless, 
the changes are in opposite directions, with an increase for court actions and a decrease for administrative actions. $^{60}$

Fourth, we examine whether an individual was charged as a defendant for actions relating to the same underlying conduct that led to the SEC's enforcement action against a public company. Corporations may be anxious to avoid liability for their officers and therefore may be willing to settle for larger penalties in order to avoid individual liability. (The SEC denies making such tradeoffs.) When the SEC has strong evidence of individual culpability, however, the agency may feel that it needs to charge an individual(s) in order to send a deterrent message. Alternatively, the charging of an individual by the SEC may indicate that the agency considers the enforcement action a high priority and is willing to devote resources to it. Figure 8 presents the trend in the fraction of SEC actions that also involve charges against an individual pre- and post-Dodd Frank for non-financial public companies.

${ }^{60}$ Consistent with changes in opposite directions, the difference pre and post Dodd Frank of the differences between the incidence of other U.S. regulator penalties for court and administrative actions is statistically significant at the $10 \%$ level. 
Figure 8: SEC Charges Against and Individual Relating to SEC Actions Against NonFinancial Public Companies

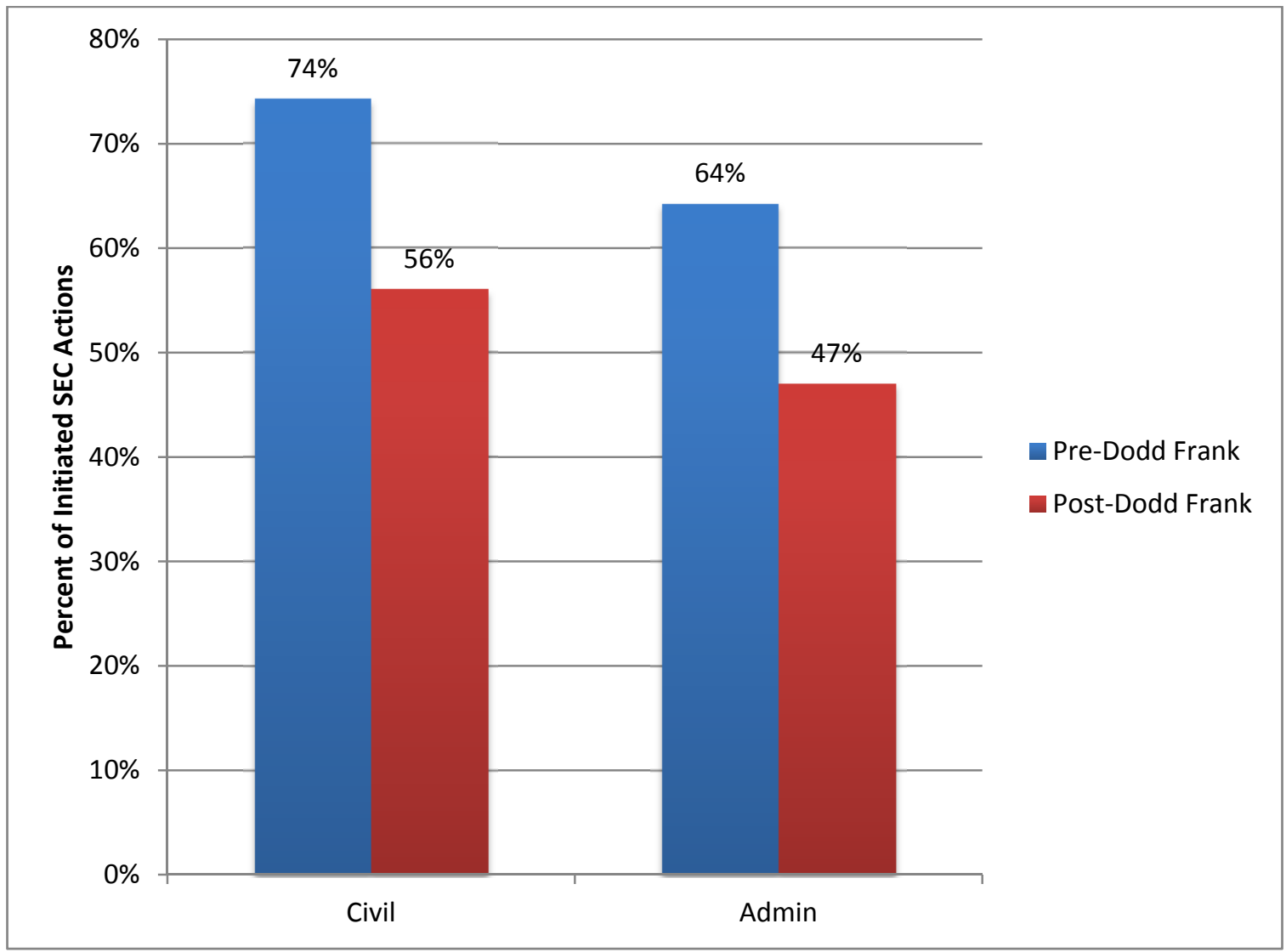

We see a decline in the fraction of SEC actions against public companies that also result in an action against an individual in both court actions and administrative proceedings. The decline in individual charges for administrative proceedings is consistent with the SEC bringing weaker (or lower priority) actions against non-financial companies through administrative proceedings in the post-Dodd Frank period. Notably, however, we also find a decline in the incidence of individual actions for civil actions as well in the post-Dodd Frank period, in contrast to our other measures of the strength or priority of the case. Both declines are significant at the $10 \%$ confidence level. Recall that we saw an increase in civil monetary penalties paid by nonfinancial public companies for both civil actions and administrative proceedings in the post- 
Dodd Frank period as depicted in Figure 2 above. These two findings, taken together, suggest that the SEC may have placed less emphasis on individual liability while pursuing greater corporate penalties post-Dodd Frank in both court and administrative proceedings. It may also suggest that the SEC is able to extract larger penalties for less culpable conduct post-Dodd Frank. Bigger penalties for public companies, combined with less culpability for individuals, suggests that the SEC is pursuing more marginal cases. The deterrent value of these marginal cases is open to question.

\section{Cooperation and Remediation}

We conjecture that the wider array of sanctions available to the SEC in administrative proceedings post-Dodd Frank would induce a higher level of cooperation from defendants. In Figure 9, we report the percentage of cases in which the SEC credited the corporation with cooperating with its investigation or engaging in remediation prior to the imposition of SEC sanctions. Although defendants in SEC enforcement actions face pressure to cooperate or engage in remediation in all actions, we use the SEC's mention of cooperation or remediation as a proxy for a high level of cooperation by the defendant. 


\section{Figure 9: Cooperation}

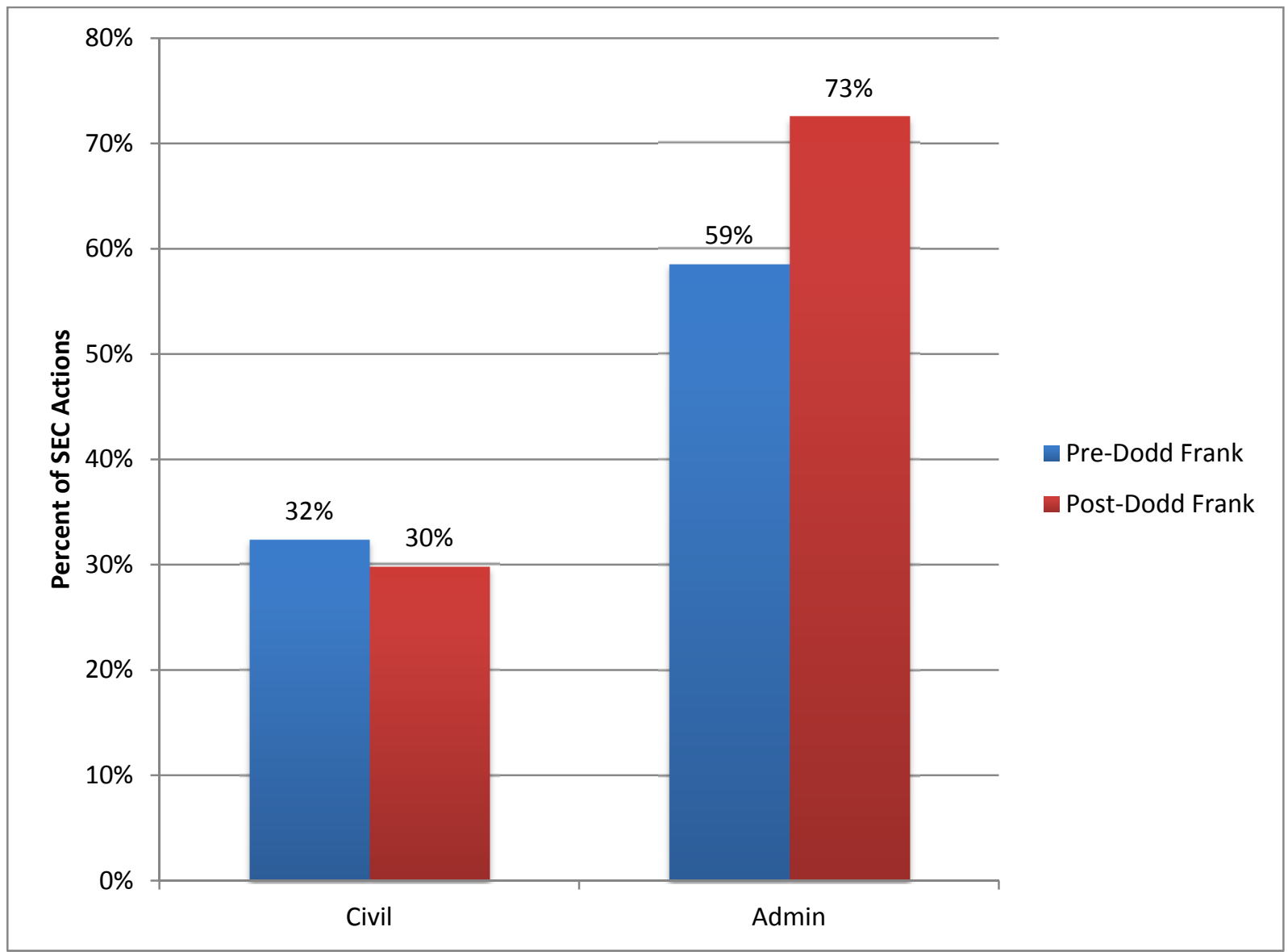

Consistent with our hypothesis, we see a sharp increase in cooperation or remediation by defendants in administrative proceedings post-Dodd Frank. Although the SEC mentioned the cooperation or remediation by the defendants in $59 \%$ of the administrative actions prior to Dodd Frank, the SEC mentioned cooperation or remediation in $73 \%$ of the administrative actions postDodd Frank. The increase is significant at the $11.5 \%$ confidence level, just beyond conventional levels of significance. In contrast, there is a small decrease in cooperation or remediation by defendants in court cases during same period that is not statistically significant. This evidence supports, to some extent, the view that the SEC wielding greater leverage when negotiating settlements in administrative proceedings. It is also consistent with the SEC shifting some settled 
cases to administrative proceedings to avoid judicial scrutiny of the fairness of the terms of the settlement.

\section{Conclusion}

Congress has gradually expanded the ability of the SEC to pursue its enforcement cases in its own administrative proceedings. The SEC has taken advantage of Dodd Frank's increase to its authority to seek civil penalties in administrative proceedings, shifting some of its cases from court to administrative tribunals. That shift has been met by constitutional challenges to the SEC's use of ALJs, as well as criticism in the media and from some members of Congress. Those challenges have focused on collateral constitutional issues, however, that the agency could easily fix. The SEC has met the criticisms of its procedures by proposing incremental reforms designed to make the process fairer for defendants.

Largely lost in the debate, however, is the question of the actual effect of the shift toward administrative proceedings. There has been some discussion about the SEC's relative win rates in court versus administrative proceedings. Win/loss rates, however, tell only a small portion of the story, as most defendants will choose to settle with the SEC rather than litigate, regardless of the forum.

In this paper, we offer evidence on the consequences of the shift toward administrative proceedings by the SEC on an important class of defendants: public companies. We show that the shift toward administrative proceedings has been accompanied by a substantial increase in the average civil penalty imposed on non-financial public companies named as defendants, both in court and in administrative proceedings. We also provide evidence that the complexity, and thus the cost, of cases the SEC brings in administrative proceedings increased after the enactment of Dodd-Frank. In contrast, the egregiousness or priority of the securities law 
violation is weaker for cases the SEC chooses to bring as administrative proceedings post-Dodd Frank. This pattern is consistent with the SEC shifting more marginal cases from court to administrative proceedings or bringing actions as administrative proceedings that would not have been brought at all pre-Dodd Frank.

Overall, we conclude that the SEC's ability to extract settlements has increased with the flexibility to choose its forum provided by Dodd Frank. The SEC appears to be bringing more cases against public companies through administrative proceedings compared with civil actions in the post-Dodd Frank period, but it is not clear that the additional cases have the same deterrent value as the mix of cases that the SEC brought prior to Dodd Frank. We do not see stronger evidence of culpability. Nor do we see other indicia that the SEC is imposing such penalties because the agency views the cases as higher priority.

Ultimately, the deterrent value of the SEC's enforcement efforts cannot be measured; it is possible that the additional cases that the SEC is able to bring post-Dodd Frank can be justified as a matter of enforcement policy. It is also possible (although less likely) that corporate wrongdoing has increased post Dodd Frank, and the SEC's efforts are simply a response. From the perspective of public companies and their shareholders, however, the SEC's shift to administrative proceedings appears to have resulted in an increase in the "enforcement tax" for securities violations. 